\title{
KETELADANAN DALAM PANEMBROMO DI DESA LANGSUR KABUPATEN SUKOHARJO JAWA TENGAH
}

\author{
Jumanto \\ Universitas Slamet Riyadi Surakarta \\ antokarof@gmail.com
}

\begin{abstract}
Considering the importance of local culture role in shaping citizens' personality and character, this research aims to analyze the values of panembromo. This research uses qualitative approach, data collection techniques using observation, interviews, study documents, and field notes. Data analysis techniques use hermeneutic analysis. The results showed that the dominant value contained in panembromo is exemplary. Exemplary value is seen on the activity of panembromo actors. The exemplary value has the potential to be implemented in school education.
\end{abstract}

Keywords: Value Exemplary, Panembromo

\begin{abstract}
ABSTRAK
Mengingat pentingnya peran budaya lokal dalam membentuk kepribadian dan karakter bangsa, penelitian ini bertujuan menganalisis nilai dalam panembromo. Penelitian ini menggunakan pendekatan kualitatif, teknik pengumpulan data menggunakan observasi, wawancara, dokumentasi, dan catatan lapangan. Teknik analisis data menggunakan analisis hermeneutik. Hasil penelitian menunjukkan bahwa nilai dominan yang terkandung dalam panembromo adalah keteladanan. Nilai keteladanan terlihat pada aktivitas pelaku panembromo. Nilai keteladanan tersebut memiliki potensi untuk di implementasikan dalam pendidikan di sekolah
\end{abstract}

Kata Kunci: Nilai Keteladan, Panembromo

\section{A. PENDAHULUAN}

Indonesia memiliki modal sosial (social capital) dan modal budaya (culture capital) untuk menjadi sebuah negara yang besar. Modal budaya tersebut maksudnya adalah pengetahuan yang dapat dipelajari dengan : 1) mengamati apa yang dilakukan (perilaku budaya); 2) mengamati benda yang digunakan misalnya pakaian dan peralatan (artefak budaya); dan 3) mendengar apa yang dikatakan/ pesan tuturan ( 
Narimo, 2014: 179). Sehingga banyak sekali sumber di masyarakat Indonesia ini untuk dijadikan bahan pendidikan nilai.

Kebudayaan jawa merupakan salah satu bagian dari kebudayaan yang ada di Indonesia. Kebudayaan jawa dengan keanekaragamannya banyak mengilhami masyarakat Jawa dalam tindakan dan perilaku keberagamaannya. Menurut Triman (2008: 7) Panembromo adalah salah satu kebudayaan jawa yang mengandung banyak nilai luhur kehidupan tetapi keberadaannya hampir hilang di masyarakat Jawa sendiri. Panembromo tidak lagi diminati oleh generasi muda yang sekarang ini lebih senang dengan budaya pop sebagai pengaruh dari kebudayaan luar.

Panembromo adalah latihan menyanyikan tembang jawa (nenmbang) yang disertai dengan pemaknaan maksudnya. Tembang untuk panembromo dipilih yang memiliki nilai luhur dalam kehidupan. Latihan nembeng tersebut dapat diiringi dengan gamelan seperti gender, slenthem, dan gambang, atau bisa juga tanpa diiringi gamelan (Prawiroatmojo, 1957: 15-19). Biasanya panembromo ini di lakukan di sanggar atau dipendopo oleh para pemuda yang dipimpin oleh tokoh masyarakat (kasepuhan) di daerah tersebut.

Lebih lanjut menurut Padmo Soekotjo (1960: 23-24) panembromo adalah latihan (gladhen) menyanyikan tembang jawa dengan nada yang tepat dan disertai pemahaman terhadap artinya. Panembromo ini dilakukan di pendopo pertemuan kampung oleh para pemuda (kaneman) dan dipimpin oleh tokoh masyarakat yang paham terhadap kesenian utamanya tembang jawa. Selain latihan nembang dan pemhaman terhadap artinya, panembromo ini juga disertai dengan pengamalan setiap nilai yang terkandung di dalam tembang yang dipelajari. Karena pemimpin dan peserta panembromo ini berasal dari kampung yang sama, maka proses penerapannya dapat di awasi oleh kasepuhan selaku pemimpin panembromo tersebut. Di sebagian daerah peserta panembromo ini disebut dengan cantrik.

Murdiati \& Untung Muljono (1983: 43) memandang panembromo bukan hanya sekedar kesenian, tetapi juga memiliki aspek pendidikan karena terdapat transfer pengetahuan dan pembetukan watak didalamnya. Panembromo ini dipimpin oleh sesepuh yang memang sudah ahli dalam tembang dan disegani dalam keseharian. 


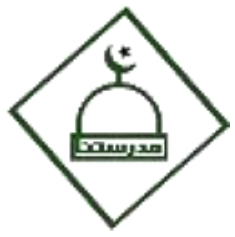

Madrosatuna: Jurnal Pendidikan Guru

Madrasah Ibtidaiyah

Volume 1 Nomor 2 (2018) 53-63

http://jurnal.iailm.ac.id/index.php/madrosatuna

Sesepuh ini disegani karena memang memiliki karakter yang baik sebagaimana karakter yang diajarkan dalam tembang yang dipelajari dalam panembromo yang dia pimpin. Tidak semua orang yang ahli dalam seni mau menjadi guru dalam panembromo, karena untuk menjadi guru dalam panembromo dituntut untuk bisa memberi teladan kepada semua cantriknya tentang nilai dari tembang tersebut. Tidak jarang tembang yang dipelajari adalah hasil gubahan guru itu sendiri sehingga guru harus mampu menjadi contoh/model/pengejawantahan bagaimana nilai dari tembang tersebut diterapkan dilingkungan sehari-hari.

Dari pendapat para ahli diatas dapat disimpulkan secara umum panembromo merupakan latihan (gladhen) menyanyikan tembang jawa dengan nada yang tepat disertai pemahaman terhadap artinya dengan diiringi atau tanpa diiringi perangkat gamelan jawa. Latihan menyanyikan tembang jawa ini harus dipimpin oleh guru yang paham kesenian musik jawa (karawitan). Biasanya guru panembromo adalah para penabuh gamelan (niyogo) atau dalang.

Kemendiknas (2010:7-8), menyebutkan nilai-nilai pendidikan dan karakter dapat diidentifikasi dari berbagai sumber diantaranya adalah dari budaya. Secara eksplisit Kemendikbud menyebutkan bahwa tidak ada manusia yang hidup bermasyarakat yang tidak didasari oleh nilai-nilai budaya yang diakui masyarakat itu. Nilai-nilai budaya itu dijadikan dasar dalam pemberian makna terhadap suatu konsep dan arti dalam komunikasi antaranggota masyarakat itu. Posisi budaya yang demikian penting dalam kehidupan masyarakat mengharuskan budaya menjadi sumber nilai dalam pendidikan budaya dan karakter bangsa. Panembromo sebagai salah satu wujud budaya Jawa tentu memiliki kandungan nilai-nilai luhur didalamnya

Kehidupan masyarakata Jawa memiliki kaitan yang erat dengan budaya dan tradisinya yang penuh dengan muatan nilai dan simbolisme. Simbolisme akan nilai tersebut nampak dalam tradisi, upacara adat maupun dalam kesenian masyarakat jawa (Herusatoto, 2008: 5). Menurut Mulyono Aji (2007: 143) panembromo juga memiliki kandungan nilai dalam masyarakat jawa, nilai tersebut antara lain: tanggung jawab, keteladanan, kerukunan/keharmonisan hidup, keindahan, dan kesopanan. Dalam penelitian ini, peneliti menggali nilai apakah yang paling nampak pada panembromo di 


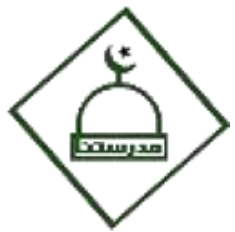

Madrosatuna: Jurnal Pendidikan Guru

Madrasah Ibtidaiyah

Volume 1 Nomor 2 (2018) 53-63

http://jurnal.iailm.ac.id/index.php/madrosatuna

desa Langsur kabupaten Sukoharjo. Serta peneliti mencoba merencanakan implementasi nilai tersebut dalam pendidikan di Sekolah Dasar.

\section{B. METODE}

Penelitian ini merupakan penelitian kualitatif dengan jenis penelitiannya adalah penelitian etnografi. Penelitian etnografi digunakan untuk mendeskripsikan, menganalisis, dan menginterpretasikan sebuah kelompok budaya yang didalamnya memiliki pola perilaku, kepercayaan, dan bahasa yang berkembang dari waktu ke waktu (Creswell, 2012).

Lokasi penelitian dilakukan di Desa Langsur Kabupaten Sukoharjo sebagai salah satu desa yang masih melestarikan budaya jawa panembromo. Subjek penelitian adalah para pelaku panembromo yang terdiri dari para murid/cantrik dan sesepuh sebagai guru nembangnya, serta warga masyarakat setempat yang sudah mengalami dan masih melestarikan budaya panembromo.

Metode pengumpulan data dalam penelitian ini dilakukan dengan cara studi literasi, wawancara dan observasi. Studi literasi digunakan untuk mengetahui definisi dari panembromo menurut berbagai ahli. Wawancara digunakan untuk mengumpulkan data terkait dengan aktivitas pelaku panembromo tersebut, baik aktivitas saat latihan, pementasan, maupun aktivitas pelaku panembromo dalam kesehariannya. Sedangkan observasi dilakukan untuk mengetahui bentuk atau format kegiatan panembromo dari latihan, perencanaan sampai pementasan, perlengkapan yang dibutuhkan, dan tembang yang di ajarkan dalam panembromo. Data yang berasal dari ketiga metode tersebut selanjutnya dianalisis untuk dapat diketahui nilai yang terkandung dalam panembromo.

\section{HASIL DAN PEMBAHASAN}

\section{Konsep Panembromo}

Konsep panembromo berdasarkan pendapat para ahli secara umum telah disimpulkan yaitu panembromo merupakan latihan (gladhen) menyanyikan tembang jawa dengan nada yang tepat disertai pemahaman terhadap artinya dengan diiringi atau 


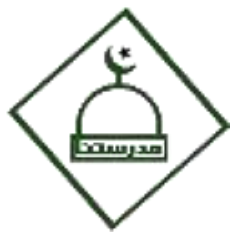

Madrosatuna: Jurnal Pendidikan Guru

Madrasah Ibtidaiyah

Volume 1 Nomor 2 (2018) 53-63

http://jurnal.iailm.ac.id/index.php/madrosatuna

tanpa diiringi perangkat gamelan jawa. Latihan menyanyikan tembang jawa ini harus dipimpin oleh guru yang paham kesenian musik jawa (karawitan).

Berdasarkan wawancara dengan sesepuh yang bernama Bapak Warno Semito pada tanggal 27 April 2018 diketahui bahwa panembromo adalah latihan nembang yang dilakukann oleh para pemuda sampai pada pementasannya. Dalam latihan tersebut juga dijelaskan arti atau kandungan nilai dalam tembang selanjutnya diterapkan dalam keseharian hidup di masyarakat. Panembromo dapat diringi musik atau tanpa iringan musik.

Berdasarkan kajian referensi dan wawancara mengenai konsep definisi panembromo, maka dapat disimpulkan bahwa panembromo adalah latihan atau gladhen melantunkan tembang jawa secara bersama-sama, disertai dengan pemaknaan nilai yang terkandung didalamnya dan juga penerapannya dalam kehidupan sehari-hari di masyarakat. Latihan dan pementasan panembromo dapat diiringi dengan gamelan ataupun tanpa diiringi gamelan

\section{Bentuk atau Format Panembromo}

Berdasarkan wawancara dengan sesepuh yang bernama Bapak Warno Semito pada tanggal 27 April 2018 diketahui bahwa latihan panembromo dilakukan seminggu sekali setiap jumat malam. Latihan dijadwalkan setelah para cantrik belajar di rumah, latihan dimulai pukul 20.00 sampai pukul 21.00. Latihan tersebut seringnya dilakukan di rumah Bapak Warno Semito namun terkadang juga di pendopo pertemuan kampung. Tembang yang dipilih dalam panembromo adalah tembang yang sejalan dengan syariat islam. Terkadang dibuat tembang sendiri berdasarkan hadist maupun ayat Al-qur'an.

Berdasarkan wawancara dengan bapak Sri Mulyadi pada tanggal 28 April 2018 diketahui bahwa untuk pementasan biasanya semua peserta akan dipentaskan setahun 3 kali yaitu pada hari peringatan kemerdekaan Republik Indonesia, pada saat acara adat syukuran panen raya atau bersih desa, dan pada saat acara maulid nabi Muhammad SAW. Tetapi terkadang pada acara adat yang dilakuakn warga Langsur (pernikahan, aqiqoh, syukuran, dll), juga ditampilkan perwakilan panembromo dengan memilih temabang yang memiliki nasihat terkait dengan acara tersebut.

Berdasarkan wawancara di atas maka dapat diketahui bahwa format panembromo di desa Langsur kabupaten Sukoharjo adalah membuat atau memilih 


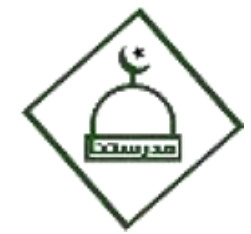

Madrosatuna: Jurnal Pendidikan Guru

Madrasah Ibtidaiyah

Volume 1 Nomor 2 (2018) 53-63

http://jurnal.iailm.ac.id/index.php/madrosatuna

tembang, latihan melantunkan tembang, mementaskan panembromo tersebut. Dalam latihan pementasan dan pementasan tidak ada upacara adat atau sesaji yang mengiringi panembromo.

\section{Aktivitas Panembromo}

Berdasarkan observasi tanggal 27 April 2018 dan 4 Mei 2018 diketahui bahwa latihan panembromo diawali dengan bapak Sri Mulyadi yang berprofesi sebagai dalang wayang kulit melantunkan 3 bait tembang dengan diiringi perangkat gamelan Jawa Tengah yaitu gender dan slenthem. Setelah itu bapak Srimulyadi dan Bapak Warno Semito bersama-sama menguraikan maksud dan arti dari tembang tersebut. Tiga bait tembang tersebut dilantunkan dengan indah dan dijelaskan maksudnya dengan jelas namun disertai humor sehingga suasana cair dan tidak mengantuk. Selain itu juga diberikan penjelasan tentang penerapan kandungan dari tembang tersebut dalam kehidupan di masyarakat sekarang ini.

Berdasarkan observasi juga ditemukan bahwa para peserta panembromo (cantrik dan sesepuh) memiliki komitmen untuk mengamalkan nasehat/nilai yang terkandung dalam panembromo tersebut. Saat latihan panembromo dijelaskan kapan dan bagaimana menerapkan nasehat/nilai yang terkandung dalam tembang panembromo tersebut. Selain itu juga disinggung perilaku cantrik dalam keseharian yang bertentangan dengan nilai yang sudah dipelajari pada panembromo yang kemarin maupun yang saat itu dibahas. Dengan penyampaian yang disertai humor, para cantrik tidak tersinggung, tapi paham maksud dari para sesepuh dan berkomitmen meperbaiki perilakunya.

Dari observasi yang telah dilakukan maka dapat diketahui bahwa aktivitas panembromo di desa Langsur Kabupaten Sukoharjo diawali dengan melantunkan tembang oleh sesepuh dengan diiringi perangkat gamelan, penjelasan nilai yang terkandung dalam tembang tersebut, latihan nembang oleh para cantrik, penjelasan penerapan dalam kehidupan di masyarakat Langsur, dan pementasan panembromo tersebut.

\section{Nilai yang Terkandung dalam Panembromo}

Kesenian memiliki peran yang penting dalam kehidupan masyarakat jawa, karena kesenian dapat digunakan sebagai transfer nilai antar generasi (Yogo Wicaksono, Herwin. 2007). Panembromo adalah adalah salah satu budaya sekaligus 


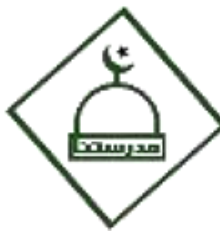

Madrosatuna: Jurnal Pendidikan Guru

Madrasah Ibtidaiyah

Volume 1 Nomor 2 (2018) 53-63

http://jurnal.iailm.ac.id/index.php/madrosatuna

kesenian musik dan suara di masyarakat jawa. Kebanyakan tembang yang dipilih dalam panembromo adalah tembang mocopat. Tembang mocopat merupakan jenis tembang yang banyak mengandung nilai-nilai substansial dalam kehidupan (Asmoro, Achmadi. 1988: 53). Oleh karena itu tembang-tembang yang dipilih dalam panembromo di desa Langsur kabupaten Sukoharjo memiliki banyak kandungan nilai substansial dalam kehidupan. Namun lebih lanjut nilai tersebut bukan hanya di pahami tetapi juga diterapkan dalam kehidupan bermasyarakat.

Berdasarkan wawancara dengan para cantrik setelah latihan panembromo yaitu tanggal 27 April 2018 dan 4 Mei 2018 diketahui bahwa mereka dituntut untuk memiliki perilaku yang baik sesuai dengan kandungan tembang dalam panembromo sehingga dapat menjadi contoh bagi adik-adiknya dikampung yang masih usia SD dan SMP. Dari wawancara tersebut juga diketahui bahwa para sesepuh panembromo semua memiliki perilaku yang baik dan menjadi teladan dalam kehidupan sosial masyarakat. Mereka menyatakan bahwa para sesepuh memiliki keimanan dan ketaqwaan yang tinggi, rajin dan tertib beribadah di masjid, ringan dalam membantu lingkungan sekitar, tidak bertindak kriminal, mabuk, minum-minuman keras, judi, berkata kotor, bahkan tidak merokok.

Berdasarkan observasi untuk mengetahui perilaku para peserta panembromo dalam keseharian pada tanggal 4-8 Mei 2018 dikonfirmasi bahwa yang dikatakan oleh para cantrik saat wawancara terbukti benar. Para sesepuh panembromo memiliki perilaku/sikap yang baik dan para cantrik yang memiliki sikap yang baik pula. Menariknya adalah sebagian besar orang dewasa alumni dari panembromo juga memiliki perilaku/sikap yang baik juga. Berdasarkan pengakuan warga bernama Joko salah satu alumni panembromo yang ditemui peneliti di pos ronda pada tanggal 6 Mei 2018, mereka (sebagian besar alumni panembromo) sadar bahwa dalam sistem masyarakat keteladanan memiliki pengaruh yang besar. Mau tidak mau, mampu tidak mampu mereka akan menjadi teladan bagi orang lain. Sehingga mereka berusaha memberikan teladan yang baik. Takut menjadi dosa yang berlipat kalau melakukan perilaku yang tidak baik.

Dari hal di atas dapat diketahui bahwa nilai dominan yang terkandung dalam panembromo adalah keteladanan. Nilai yang lain juga muncul, misalnya tanggung 


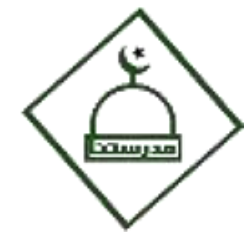

Madrosatuna: Jurnal Pendidikan Guru

Madrasah Ibtidaiyah

Volume 1 Nomor 2 (2018) 53-63

http://jurnal.iailm.ac.id/index.php/madrosatuna

jawab, dan kerukunan, tetapi nilai keteladan paling berpengaruh dalam kehidupan para pelaku dan alumni panembromo di desa Langsur Kabupaten Sukoharjo

\section{Letak Nilai Keteladanan}

Masyarakat jawa sangat menjunjung etika dalam kehidupannya. Etika tersebut menjadikan masyarakat jawa memiliki ciri khas tersendiri dalam hidup berkebangsaan (Suseno, Franz Magnis. 1996: 4). Banyak perilaku masyarakat jawa yang berdasarkan falsafah yang diturunkan dari generasi ke generasi. Falsafah tersebut pada akhirnya membentuk karakter dan etos kerja masyarakat jawa (Endraswara, Suwardi. 2006: 7). Hal tersebut sesuai dengan pendapat Soeharto (1987: 29) yang menyatakan bahwa manusia dapat mengambil pelajaran dan nilai dari budaya dan kesenian untuk mendapatkan kehidupan yang lebih baik. Dalam panembromo yang merupakan salah satu bentuk kesenian masyarakat Jawa mengandung nilai luhur untuk kehidupan. Nilai tersebut adalah nilai keteladanan yang disadari dan juga dipratekkan oleh masyarakat sekitar Desa Langsur Kabupaten Sukoharjo.

Nilai keteladanan dalam panembromo di Desa Langsur Kabupaten Sukoharjo terletak pada aktivitas oleh para pelaku panembromo. Nilai keteladanan tersebut terlihat saat latihan, pementasan, bahkan saat keseharian para pelaku panembromo. para murid/cantrik dalam keseharian memiliki perilaku yang baik sesuai dengan kandungan tembang dalam panembromo sehingga dapat menjadi contoh bagi adik-adiknya dikampung yang masih usia SD dan SMP. Hal ini tidak terlepas dari doktrinasi guru panembromo bahwa para cantrik harus dapat menjadi contoh dalam kehidupan bermasyarakat. Selain itu stigma masyarakat yang beranggapan bahwa menamatkan panembromo merupakan salah satu pembuktian menjadi dewasa.

Semua sesepuh sebagai guru panembromo juga memiliki perilaku yang baik dan menjadi teladan dalam kehidupan sosial masyarakat. Para sesepuh memiliki keimanan dan ketaqwaan yang tinggi, rajin dan tertib beribadah di masjid, ringan dalam membantu lingkungan sekitar, tidak bertindak kriminal, mabuk, minum-minuman keras, judi, berkata kotor, bahkan mereka tidak merokok. Karena sadar menjadi teladan bagi para cantriknya, para sesepuh selalu menjaga perbuatan dan perkataannya serta menampilkan semangat belajar ilmu agama.

\section{Nilai Guna}




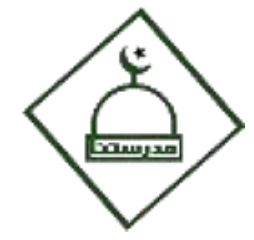

Madrosatuna: Jurnal Pendidikan Guru

Madrasah Ibtidaiyah

Volume 1 Nomor 2 (2018) 53-63

http://jurnal.iailm.ac.id/index.php/madrosatuna

Dari pemaparan di atas dapat diketahui bahwa keteladan mampu mendorong seseorang untuk berpikir yang baik, berkata yang baik, dan berbuat yang baik. Oleh karena itu keteladan memiliki nilai guna yang besar dalam pendidikan. Keteladanan merupakan salah satu hal yang meyakinkan dalam pendidikan, apalagi dalam pendidikan karakter. Dalam konsep pendidikan karakter, Ki Hadjar Dewantara dan K.H. Ahmad Dahlan sama-sama mengedepankan prinsip keteladanan dan pentingnya penyadaran melalui proses dialog dalam mengajarkan karakter dalam rangka menghindari indoktrinasi. Figur guru di sekolah bertugas memberi contoh atau menjadi suri tauladan terlebih dahulu, sebelum mengajarkan segala hal baik yang harus diikuti oleh siswa. Begitu juga orang tua di rumah sebelum menanamkan nilai kebaikan, maka orang tua harus menjadi contoh yang baik terlebih dahulu.

Peran keteladanan dalam pendidikan tidak bisa diragukan lagi. Tanpa keteladanan proses pendidikan ibarat jasad tanpa ruh. Karena naluri mencontoh merupakan satu naluri yang kuat dan berakar dalam diri manusia, dan naluri ini akan semakin menguat. Menyadari hal tersebut, keteladanan dapat dijadikan modal dalam mengelola dan mewujudkan pendidikan karakter. Menjadikan pendidik memiliki karakter yang baik, dan menjadikan peserta didik berlatih untuk memiliki karakter yang baik melalui contoh yang nyata. Sehingga aplikasi dari nilai keteladan panembromo di sekolah memungkinkan diselenggarakannya sekolah berbasis Keteladanan Panembromo.

\section{SIMPULAN DAN REKOMENDASI}

\section{Simpulan}

Berdasarkan penelitian dilapangan dan didukung pengkajian literasi maka dapat disimpulkan bahwa definisi panembromo yang ada di desa Langsur kabupaten Sukoharjo adalah latihan atau gladhen melantunkan tembang jawa secara bersamasama, disertai dengan pemaknaan nilai yang terkandung didalamnya dan juga penerapannya dalam kehidupan sehari-hari di masyarakat. Latihan dan pementasan panembromo dapat diiringi dengan gamelan ataupun tanpa diiringi gamelan.

Format panembromo adalah membuat atau memilih tembang, latihan melantunkan tembang, dan mementaskan panembromo tersebut. Dalam latihan 


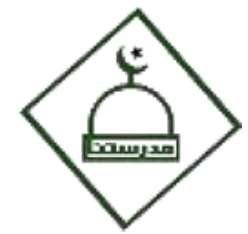

Madrosatuna: Jurnal Pendidikan Guru

Madrasah Ibtidaiyah

Volume 1 Nomor 2 (2018) 53-63

http://jurnal.iailm.ac.id/index.php/madrosatuna

pementasan dan pementasan tidak ada upacara adat atau sesaji yang mengiringi panembromo. Sedangkan aktivitas dari panembromo tersebut diawali dengan melantunkan tembang oleh sesepuh dengan diiringi perangkat gamelan, penjelasan nilai yang terkandung dalam tembang tersebut, latihan nembang oleh para cantrik, penjelasan penerapan dalam kehidupan di masyarakat Langsur, dan pementasan panembromo tersebut.

Nilai dominan yang terkandung dalam panembromo adalah keteladanan. Nilai yang lain juga muncul, misalnya tanggung jawab, dan kerukunan, tetapi nilai keteladan paling berpengaruh dalam kehidupan para pelaku dan alumni panembromo di desa Langsur Kabupaten Sukoharjo. Nilai keteladanan dalam panembromo di Desa Langsur Kabupaten Sukoharjo terletak pada aktivitas oleh para pelaku panembromo. Nilai keteladanan tersebut terlihat saat latihan, pementasan, bahkan saat keseharian para pelaku panembromo.

Nilai guna dari keteladan dalam panembromo adalah dapat dijadikan modal dalam mengelola dan mewujudkan pendidikan karakter. Menjadikan pendidik memiliki karakter yang baik, dan menjadikan peserta didik berlatih untuk memiliki karakter yang baik melalui contoh yang nyata. Sehingga aplikasi dari nilai keteladan panembromo di sekolah memungkinkan diselenggarakannya sekolah berbasis Keteladanan Panembromo.

\section{Rekomendasi}

Masih banyak hal yang dapat dikaji terkait dengan penelitian ini. Sehingga penelitian ini dapat dilanjutkan dengan penelitian lain dengan lebih mendalam. Penelitian bidang antropologi terkait perilaku para pelaku panembromo, penelitian terkait bimbingan dan konseling yang dilakukan oleh sesepuh panembromo terhadap mayarakat sekitar, penelitian bidang pendidikan terkait pendidikan karakter dalam masyarakat panembromo, merupakan beberapa topik penelitian yang penulis rekomendasikan untuk diteliti.

Khususnya untuk praktek pendidikan, penulis merekomendasikan untuk meningkatkan peran keteladan guru dan wali murid untuk mensukseskan pendidikan karakter. Pendidikan karakter yang holistik dan berkelanjutan dari sekolah ke rumah dan lingkungan masyarakat melalui keteladan yang baik. 


\section{REFERENSI}

Murdiati \& Untung Muljono. (1983). Dasar-Dasar Belajar Tembang Gaya Yogyakarta. Yogyakarta: Akademi Seni Tari Indonesia

Padmo Soekotjo, S. (1960). Ngengrengan Kasusastran Djawa II. Yogyakarta: Hien Hoo Sing.

Prawiroatmojo, S. (1957). Bausastra Jawa Indonesia. Surabaya.

Yogo Wicaksono, Herwin. 2007. Peranan Etnomusikologi Dalam Pendidikan Dasar, Seminar Nasional Pendidikan Seni Musik, Jurusan Seni Musik Fakultas Bahasa dan Seni Universitas Negeri Yogyakarta.

Asmoro, Achmadi. 1988. Nilai-nilai Substansial dalam Macapat. Tesis Magister, tidak diterbitkan. Yogyakarta: Universitas Gadjah Mada.

Endraswara, Suwardi. 2006. Falsafah hidup Jawa. Yogyakarta: Cakrawala

Herusatoto, Budiono. 2008. Simbolisme Jawa. Yogyakarta: Ombak

Soeharto. 1987. Butir-butir budaya Jawa: Hanggayuh kasampurnaning Hurip Berbudi Bawaleksana Ngudi Sajating Becik. Jakarta: Cendana.

Suseno, Franz Magnis. 1996. Etika Jawa Sebuah Analisa Filsafat Tentang Kebijaksanaan Hidup Jawa. Yogyakarta : Kanisius

Kementrian Pendidikan Nasional (Kemendiknas). 2010. Pengembangan Pendidikan Budaya dan Karater Bangsa. Pedoman Sekolah. Jakarta: Badan Penelitian dan Pengembangan Pusat Kurikulum.

Triman. 2008. Budaya Lintas Masa di Tanah Jawa. Surakrta: ISI Press 